\title{
Radiobiogeochemical Assessment of the Soil Near the Issyk-kul Region
}

Djenbaev Bekmamat, Kaldybaev Bakit, Toktoeva Tamara and Kenjebaeva Aigul

Biology \& Pedology Institute of National Academy of Science, Chui Ave 265, Bishkek 720071, Kyrgyz Republic

Abstract: The results of researches are presented the concentration of humus, macro and trace elements and radionuclide in the soil of the Issyk-Kul region. It has given radio biogeochemical assessment of the current status of soils investigated region.

Key words: Soil, radionuclide, radiation background, radioactive tailing, Issyk-Kul region.

\section{Introduction}

In Kyrgyzstan, there are a number of natural and man-made areas that require complex radio biogeochemical research. One of these regions the "Biosphere Reserve Issyk-Kul" was formed in 2001, which includes the basin of lake Issyk- Kul, mountains Teskey and Kungey Ala-Too.

The main source of uranium in the Issyk-Kul basin are rocks with elevated its content. The weathering of these rocks are formed easily movable uranium, which are concentrated in the humus soil horizons (A, B). Soil is one of the main natural resources, providing for the sustainable development of the country. For environmentally well founded and balanced use and protection of land resources is necessary to create the optimal structure of arable farming, minimizing negative impacts on the land of diverse agricultural activities. In this connection, we have been tasked to assess the current radiobiogeochemical condition of soil near the Issyk-Kul region [1-3].

\section{Materials and Methods}

In the selection of soil samples, we used soil classification adopted in the preparation of the soil map of the Kyrgyz SSR [4]. Soil sampling was carried out in

Corresponding author: Bekmamat M. Djenbaev, Dr., professor, research fields: geosciences, bioreochemistry and coordinator. accordance with GOST 28168-89 "Soils Sampling” [5]. To carry out the gamma survey area used dosimeter DKS-96 (Russia). General analysis of soil was carried out in the Republican soil-agrochemical station. Determination of chemical elements in the soil was carried out by $\mathrm{X}$ spectrometer firm Ortec (USA) SLP-10180 P, the method of instrumental radionuclide gamma-ray spectrometry by gamma spectrometer firm Canberra (USA), consisting of a germanium detector HPGe at the Biology \& Pedology Institute of National Academy of Science Kyrgyz Republic. Statistical analysis was performed using the application Microsoft Excel for Windows 2000, Statistics for Windows 6.0.

\section{Results and Discussion}

Radiometric survey found that the level of radiation relatively low, ranging from 5 to $50 \mathrm{mR} / \mathrm{hr}$ in the Issyk-Kul Biosphere Territory. About $87 \%$ of 5-23 $\mathrm{mR} / \mathrm{hr}, 8 \%-36 \mathrm{mR} / \mathrm{h}, 4 \%-47 \mathrm{mR} / \mathrm{h}, 1 \%$-above 50 $\mathrm{mR} / \mathrm{h}$. According to the Radiation Safety Standards - in 2009 the level of background radiation exposure dose should not exceed $60 \mathrm{mR} / \mathrm{h}$ (Fig. 1).

Small areas with high natural background radiation:

- Individual sections of the coastal strip of lake Issyk-Kul give increased radiation background. Coastal zones beaches of the villages Jenish and Ak-Terek located on the southern shore of lake Issyk-Kul, their radioactivity is $30-60 \mathrm{mR} / \mathrm{h}$, and in some 


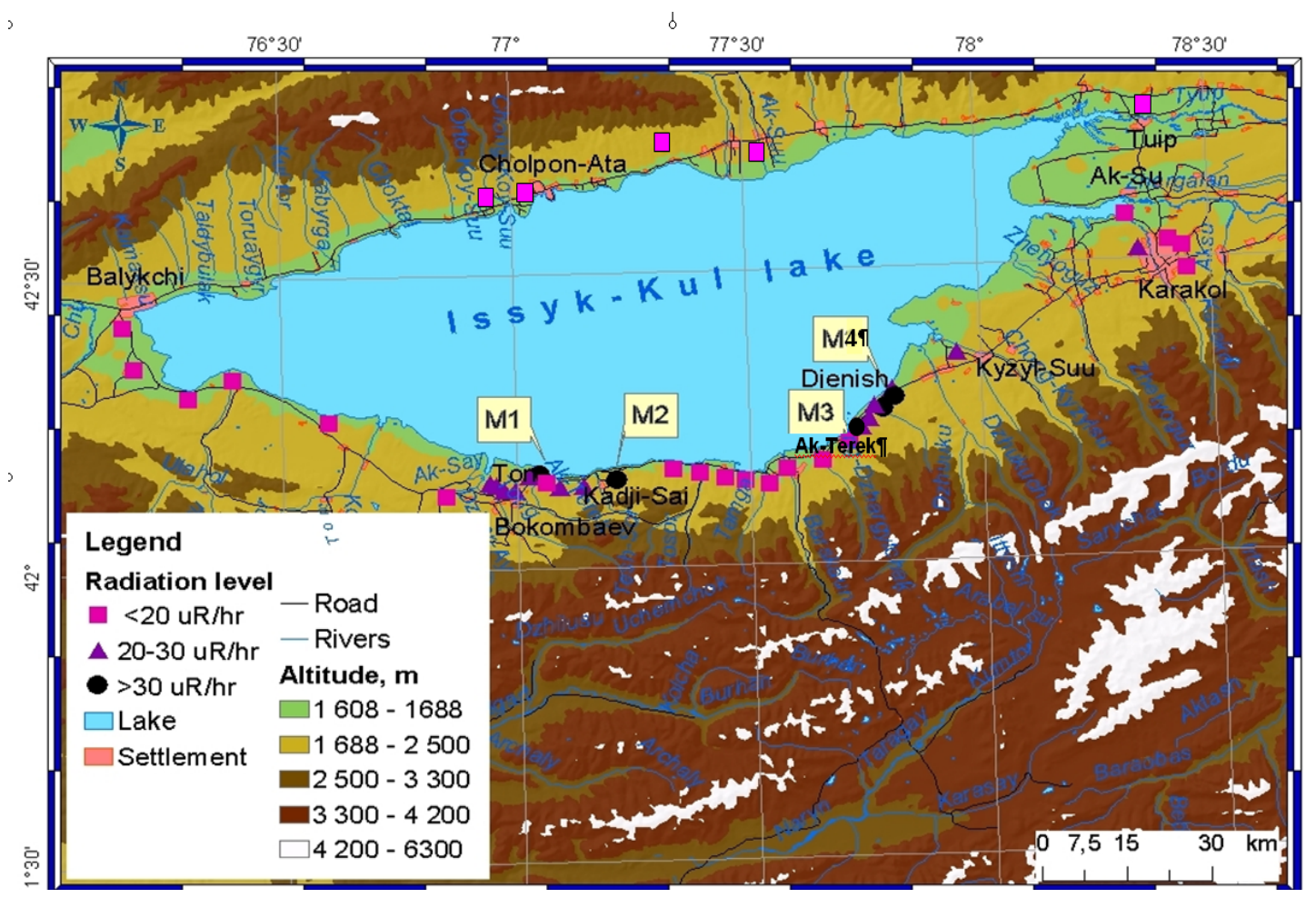

Fig. 1 Schematic map of the exposure of external gamma radiation in coastal of Issyk-Kul lake.

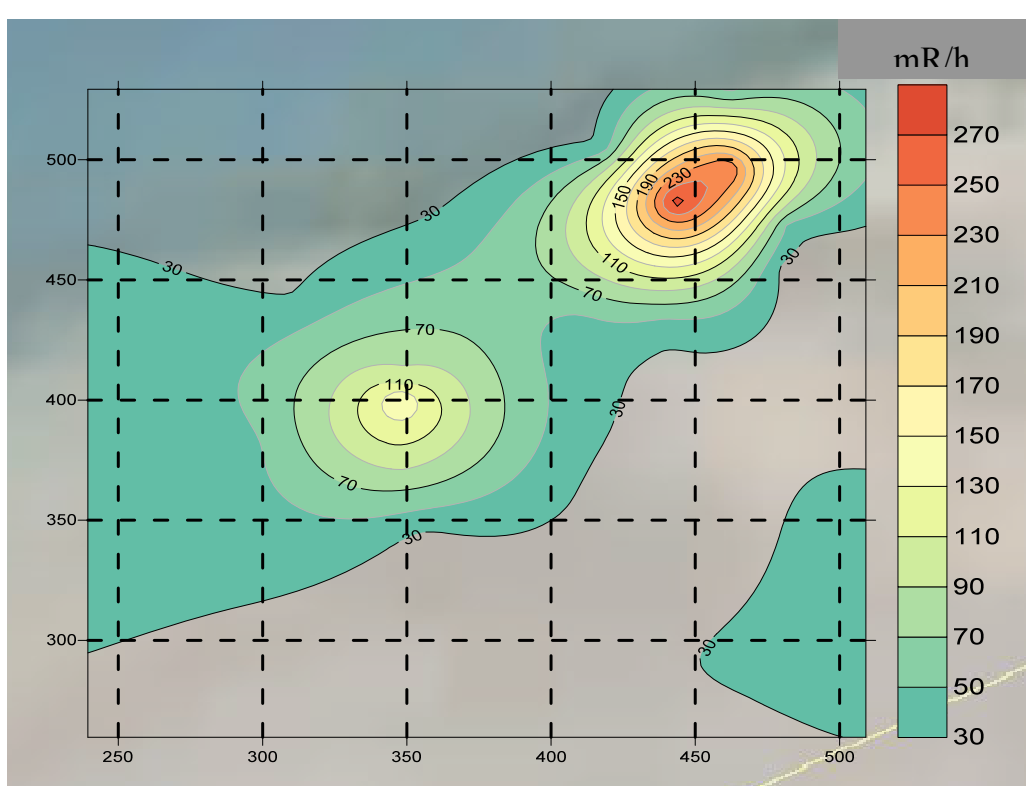

Fig. 2 Scheme of spatial distribution of power of gamma dose on coastal zones beaches of the villages Jenish and Ak-Terek located on the southern shore of lake Issyk-Kul.

places up to $200 \mathrm{mR} / \mathrm{hr}$ (Fig. 2);

- Mountainous terrain, gorges which are based on granite, rocky ground, the red sand containing natural radionuclides $(\mathrm{U}, \mathrm{Th}, \mathrm{Ra})$ giving increased radiation background $25-50 \mathrm{mR} / \mathrm{h}$.
The sites of investigated region were presented upland-lowland light brown, brown, dark brown soils, mechanical composition is mainly medium loam. Humus concentration varies between 2.3-4.3\%, which is the characteristic value types investigated region. 
Soil sufficiently secured mineral elements, the concentration of total nitrogen varies in the redistribution of $0.11-0.18 \%$, phosphorus $0.15-0.19 \%$, $2.0-2.4 \%$ potassium. These soils are mainly weakly calcareous $0.2-1.8 \%$. The reaction of soil solution is alkaline 8.0-8.4.

The absorption capacity is $14-24 \mathrm{mg}$. Equivalents per $100 \mathrm{~g}$ soil and closely correlates with the content of humus in the soil $(r=0.99, p<0.05)$. The results of agrochemical soil analyzes are presented in Table 1 .

Determination of chemical elements in the soil was conducted by the methods of X-ray fluorescence analysis and radionuclide by the methods of instrumental gamma spectrometry (Table 2). The results of research were given that:

(1) Macro and microelements are contained in different concentration in the soil, not enough ( $\mathrm{Ti}, \mathrm{Cr}$, $\mathrm{Mn}, \mathrm{Fe}, \mathrm{Ni}, \mathrm{Ga}, \mathrm{Sr}, \mathrm{Y}, \mathrm{Zr}, \mathrm{Nb}, \mathrm{Bi}$ ), within the limit of norm (N, P, K, Ca, Cu, Zn, Ge, Br, Rb, Mo, Ba, La, Ce), the accumulation of the weak characteristic for $(\mathrm{V}, \mathrm{As}$, $\mathrm{Sb}, \mathrm{Nd}, \mathrm{Pb}, \mathrm{U}, \mathrm{Th}, \mathrm{Ra})$, the average (Co, Cs), strong (Sn ). Isotopes of radioactive elements $\left({ }^{238} \mathrm{U},{ }^{232} \mathrm{Th}\right.$, ${ }^{226} \mathrm{Ra},{ }^{40} \mathrm{~K}$ ) are characterized by weak accumulation in the soil;

(2) It was exposed the positive correlation dependence between the concentration of humus, absorption capacity and the concentration of chemical elements in soils for: Ti, V, Cr, Mn, Fe, Sr, Mo, Ba. In the case of $\mathrm{Sr}(\mathrm{r}=0.55 ; \mathrm{p}<0.05)$, and $\mathrm{Ba}(\mathrm{r}=0.6 ; \mathrm{p}<$ $0.05)$ is correct. For other chemical elements and radionuclide the correlation dependence is negative.

In the distant past (at the end 40 years of XX century), Kyrgyzstan was the largest producer of uranium oxide for the defense industry of the USSR. In the country a number of enterprises of mining and processing of uranium ore were worked and it is technogenic uranium plot "Kadji-Say", it is located on the southern shore of lake Issyk-Kul. Mining Enterprise Ministry of Medium Machine Building of the USSR by uranium ore processing operation have been worked from 1948 to 1969 , he was subsequently converted into electro technical factory.

Uranium oxide was extracted from uranium-containing ash brown coals. Production wastes were buried, forming tailings, with a total volume of 400 thousand $\mathrm{m}^{3}$ [6-9]. On the territory of the tailings the level of exposure dose of gamma radiation varies within the limit of $100-300 \mathrm{mR} / \mathrm{h}$ in some places up to $1,000 \mathrm{mR} / \mathrm{h}$. In the surface of the soil layer of tailing radioactive elements were contained in different concentrations:

The high concentration of $U(76 \mathrm{mg} / \mathrm{kg})$, the specific activity of ${ }^{238} \mathrm{U} /{ }^{234} \mathrm{Th}$ total $851.6 \mathrm{~Bq} / \mathrm{kg}$. A lot of ${ }^{226} \mathrm{Ra}$ $(3,800 \mathrm{~Bq} / \mathrm{kg})$, it was broken radioactive balance between ${ }^{234} \mathrm{Th} /{ }^{226} \mathrm{Ra}$, indicating the presence of uranium leaching processes. The high concentration of thorium ${ }^{228} \mathrm{Ac}(97.7 \mathrm{~Bq} / \mathrm{kg}),{ }^{235} \mathrm{U}(39.5 \mathrm{~Bq} / \mathrm{kg})$ (Table 3). Low activity of the artificial radionuclide ${ }^{137} \mathrm{Cs}$ (2.1 $\mathrm{Bq} / \mathrm{kg}$ ), which is typical for mountainous terrain.

Nonradioactive element-indicators:

Table 1 Agrochemical indicators of soil near the Issyk-Kul region.

\begin{tabular}{|c|c|c|c|c|c|c|c|c|}
\hline \multirow{2}{*}{ Place of test } & \multirow{2}{*}{$\begin{array}{l}\text { Type } \\
\text { soil }\end{array}$} & \multirow{2}{*}{$\begin{array}{l}\text { Humus, } \\
\%\end{array}$} & \multirow{2}{*}{$\begin{array}{l}\mathrm{CO}_{2} \\
\%\end{array}$} & \multirow{2}{*}{$\mathrm{pH}$} & \multirow{2}{*}{$\begin{array}{l}\text { Absorption capacity } \\
\text { mg-eq. }\end{array}$} & \multicolumn{3}{|c|}{ Total $\%$} \\
\hline & & & & & & $\mathrm{N}$ & $P$ & $\mathrm{~K}$ \\
\hline $\begin{array}{l}\text { Village } \\
\text { Grigorievka }\end{array}$ & $\begin{array}{l}\text { Light } \\
\text { brown }\end{array}$ & $4.3 \pm 0.3$ & $1.1 \pm 0.1$ & $8.3 \pm 0.5$ & $24 \pm 1.6$ & $0.18 \pm 0.03$ & $0.17 \pm 0.03$ & $2.0 \pm 0.15$ \\
\hline $\begin{array}{l}\text { Village } \\
\text { Tup }\end{array}$ & Brown & $3.8 \pm 0.2$ & $0.2 \pm 0.03$ & $8.0 \pm 0.6$ & $22.6 \pm 1.8$ & $0.16 \pm 0.03$ & $0.15 \pm 0.03$ & $2.4 \pm 0.18$ \\
\hline $\begin{array}{l}\text { Village } \\
\text { Maman }\end{array}$ & $\begin{array}{l}\text { Dark } \\
\text { brown }\end{array}$ & $3.3 \pm 0.2$ & $0.13 \pm 0.01$ & $8.3 \pm 0.7$ & $19.6 \pm 1.7$ & $0.17 \pm 0.02$ & $0.17 \pm 0.02$ & $2.3 \pm 0.15$ \\
\hline $\begin{array}{l}\text { Village } \\
\text { Barskoon }\end{array}$ & $\begin{array}{l}\text { Light } \\
\text { brown }\end{array}$ & $2.3 \pm 0.1$ & $1.8 \pm 0.2$ & $8.4 \pm 0.7$ & $14.0 \pm 1.4$ & $0.11 \pm 0.02$ & $0.19 \pm 0.04$ & $2.0 \pm 0.13$ \\
\hline $\begin{array}{l}\text { Village } \\
\text { Tone }\end{array}$ & $\begin{array}{l}\text { Light } \\
\text { brown }\end{array}$ & $2.4 \pm 0.1$ & $0.9 \pm 0.1$ & $8.4 \pm 0.4$ & $14.2 \pm 1.5$ & $0.11 \pm 0.02$ & $0.16 \pm 0.03$ & $2.4 \pm 0.16$ \\
\hline
\end{tabular}


Table 2 The concentration of radionuclide in the soil near the Issyk-Kul region.

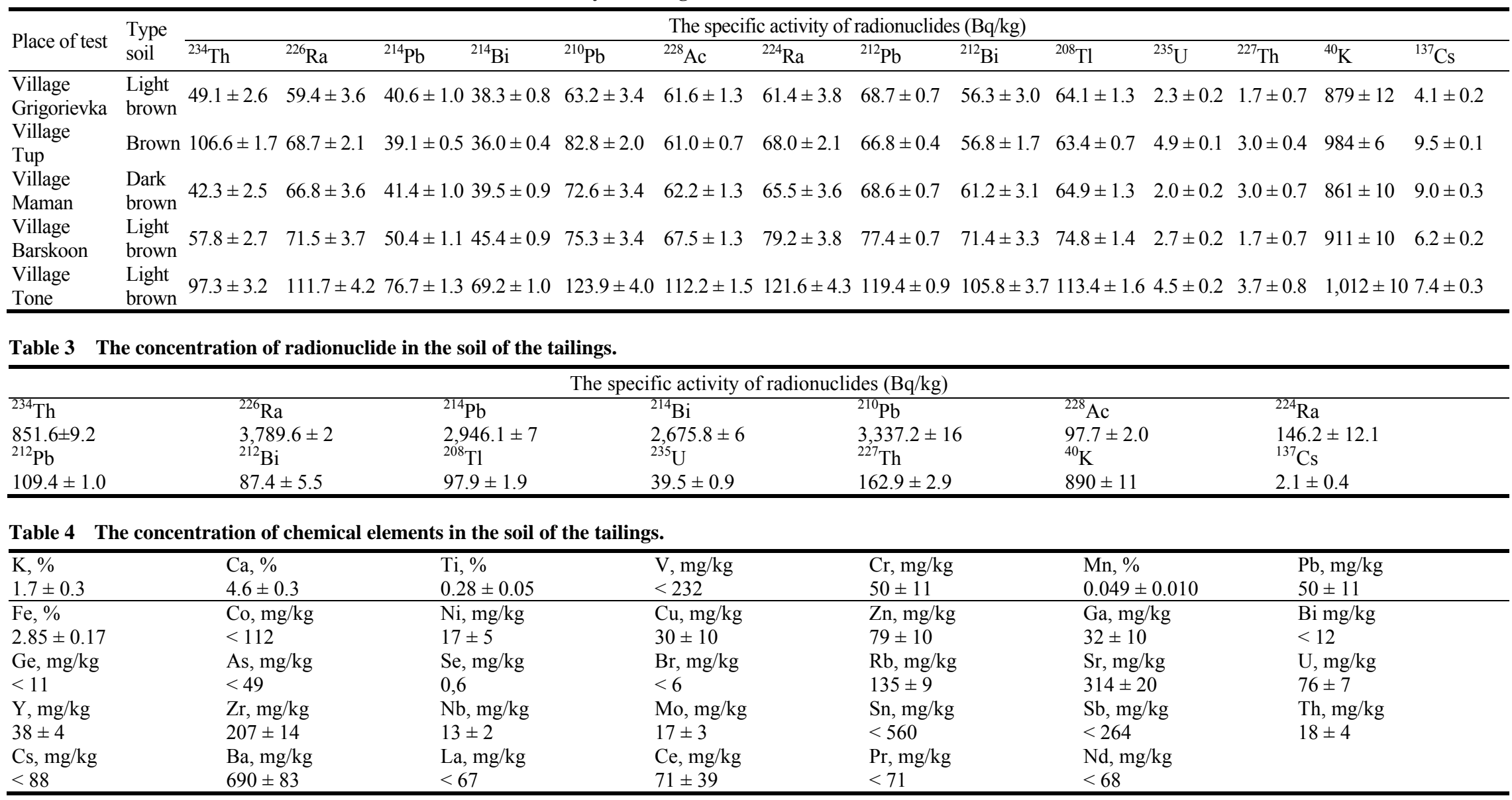


The high concentration of Co-112 mg/kg, the concentration of clark (Cc-14). The high concentration of As-49 mg/kg (Cc-9.8); Mo-17 mg/kg (Cc-8.5); $\mathrm{Pb}-50 \mathrm{mg} / \mathrm{kg}$ (Cc-5); V-232 mg/kg (Cc-2.32). Within the limit of norm concentration: $\mathrm{Cu}-30 \mathrm{mg} / \mathrm{kg}$ (Cc-1.5) and $\mathrm{Zn}-79 \mathrm{mg} / \mathrm{kg}$ (Cc-1.58); the low concentration: $\mathrm{Ni}-17 \mathrm{mg} / \mathrm{kg}(\mathrm{Cc}-0,42)$ and $\mathrm{Bi}-12 \mathrm{mg} / \mathrm{kg}$ (Cc-0.24) (Table 4).

That's way, the results of research have shown that on the surface layer of soil of the tailing between the radioactive elements contain the high concentrations of uranium and radium and accompanying non-radioactive elements, such as selenium, cobalt, arsenic, lead and vanadium.

\section{Conclusions}

Our results indicate that the average radioactivity of soil Issyk-Kul basin is low, it can be regarded as a conditional radiogeochemical background of the region (which for the uranium- radium determined by the values between 35 and $55 \mathrm{~Bq} / \mathrm{kg}$ ). The overall level of external radiation background is normal, except for some local sites of natural and manmade.

Increased radioactivity characterized by:

- For some mountain areas, which are based on granite, small fragments of red sand, carbonaceous-siliceous shales, as well as coastal zones beaches of the villages Jenish and Ak-Terek located on the southern shore of lake Issyk-Kul with enhanced natural radioactivity;

- Radioactive tailings area of man-made "Kaji-Sai", where the exposure dose in the tens or hundreds of times higher than background values. On the territory of the man-made area will require further engineering work to restore the protective layer of the tailings should enclose the area of the tailings, install special signs warning of the presence of radioactive contamination. Along with the engineering work necessary to carry out activities phytomeliorative-landscaped dumps and tailings, keep away from water and wind erosion.

\section{References}

[1] Djenbaev, B., Kaldybaev, B., and Jolboldiev, B. 2009. "Radiobiogeochemical Assessment of the Current State of the Biosphere Territory of Issyk-Kul." Book of Int. Conf. "Modern Problems of Geoecology and Biodiversity Conservation”, 77-81.

[2] Djenbaev, B., Shamshiev, A., and Jolboldiev, B. 2008. "The Biogeochemistry of Uranium in Natural-Technogenic Provinces of the Issik-Kul." Uranium, Mining and Hydrogeology, 673-80.

[3] Kowalski, V., Vorotnitsky, I., and Lekarev, V. 1968. "Uranium Biogeochemical Food Chains in the Conditions of the Issyk-Kul Basin." In Proceedings of the Biogeochemical Laboratory, 25-53.

[4] Mamytov, A. 1996. Soil Resources and Land Registry Issues of the Kyrgyz Republic, 240.

[5] GOST 28168-89. 1989. Soil sampling, 7.

[6] Aitmatov, I., Torgoev, I., and Aleshin, Y. 1997. "Geoenvironmental Problems in the Mining Complex in Kyrgyzstan.” Science and New Technologies 1: 81-95.

[7] Bykovchenko, Y., Bykova, E., and Belekov, T. 2005. Man-Caused Pollution of the Biosphere with Uranium in Kyrgyzstan, 169.

[8] Karpachev, B., and Meng, S. 2000. Radiation-Ecological Research in Kyrgyzstan, 56.

[9] Torgoev, I., and Aleshin, Y. 2009. Geoecology and Waste Mining Complex in Kyrgyzstan, 240. 